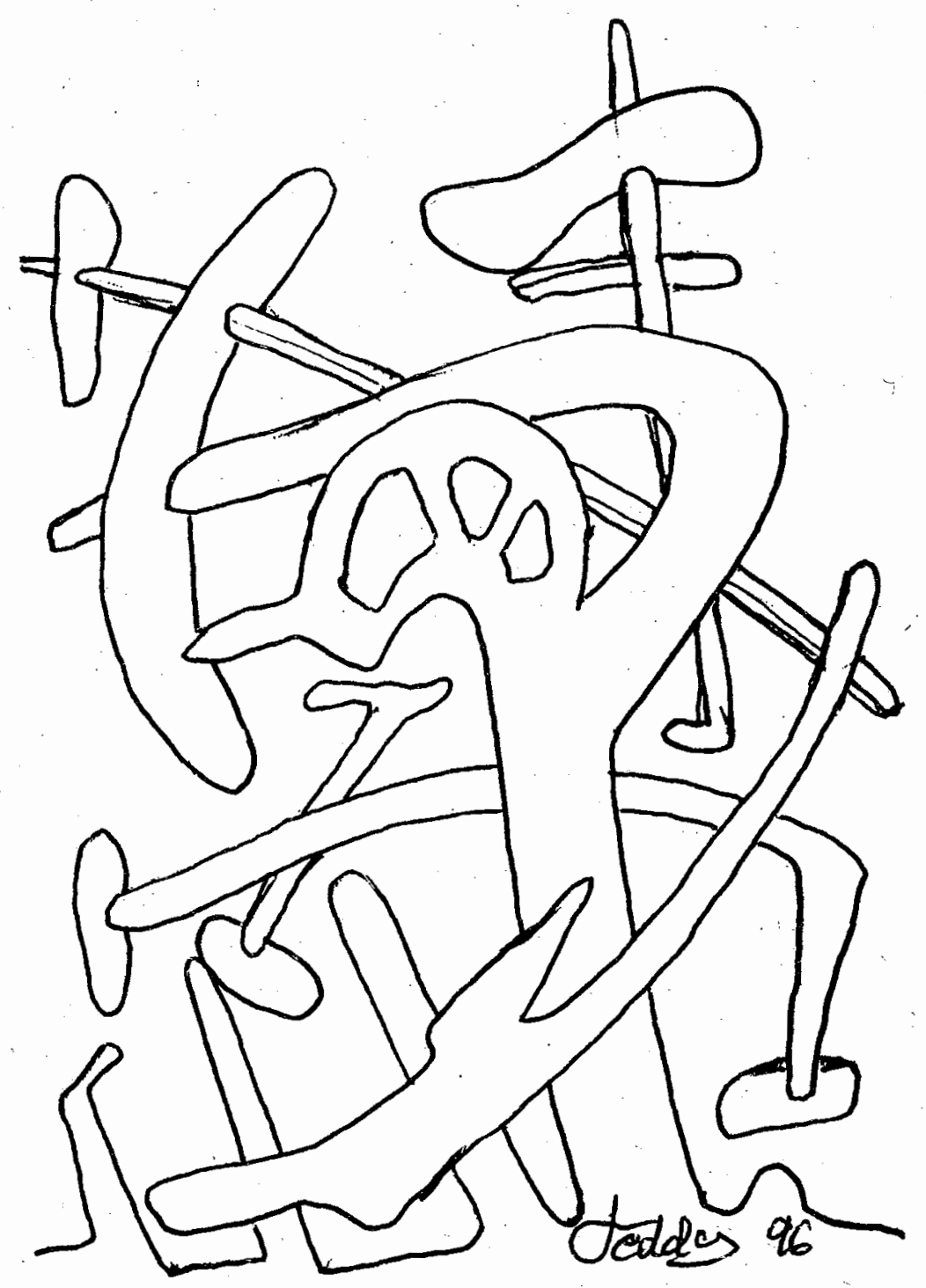

\title{
Panoramisk urbanisering
}

Paris som medie hos Balzac og i 1800-tallets realistiske medievirkelighed

SØREN POLD

"Das neue Medium resümiert die Formprobleme seiner Zeit." (Bolz, p. 104)

I 1833 er Paris, det nittende århundredes hovedstad, blevet for stor og dynamisk til, at den kan overskues som et sted. Et perspektivisk overblik over stedet er ikke længere tilstrækkeligt. Byen består selvfølgelig stadig både af mursten, gader og mennesker, som alt sammen er synligt for overblikket. Men mellem murstenene, gaderne og menneskene, i og imellem det gamle Paris' kvarterer, opstår en særlig kommunikation, som det perspektiviske overblik ikke kan rumme. En urban massebevidsthed, som både præger og er præget af byen, vokser frem, og den synlige by fordobles i et tegnsystem som følge af, at mennesket „stræber mod at repræsentere sine sæder, sine tanker og sit liv i alt, hvad det tilegner sig til sine behov." (Balzac: Avant propos, I, p. 5). ${ }^{1}$

Denne massebevidsthed med dens særlige tegnsystem er et konstant tilbagevendende tema for Balzac under navnet la société. Adressen i den fysiske by er stadig en vigtig referent, da de forskellige klasser ordnes i deres respektive kvarterer, hvor de samtidig repræsenterer deres klasses kendetegn. Men der er ikke fuld kompatibilitet eller stabilitet mellem byen og dens tegnsystem eller massebevidsthed. Adresserne udskiftes og folk træffes 
i forkerte kvarterer med dunkle motiver og for at pleje obskure forbindelser. Kort sagt bliver storbyen til et tegnsystem som individet både er underlagt og samtidig kan benytte sig af via forskellige strategier.

Det er på grundlag af denne ustabilitet og med øje for storbyens nye tegnsystem, at den realistiske forfatter Honoré de Balzac projekterer den moderne Paris- og storby-roman med Ferragus og konstruerer den med Le père Goriot. ${ }^{2}$ Begge romaner arbejder med at overskue og erkende byen, men de har samtidig begge et klart blik for byens moderne uoverskuelighed. Igennem romanerne sker der et skred fra en indledende altseende fortællerposition, som opløses igennem romanerne for at slutte med en ny form for overskuelighed i et panoramisk blik.

Umiddelbart kunne dette afsluttende panoramiske overblik ligne en tilbagevenden til det indledende centralperspektiviske overblik, og ofte forstår man panorama som blot et synonym for overblik. Men dermed overser man det væsentlige paradigmatiske skift, der indledtes omkring år 1800; en „riven synet op med rode fra det stabile og faste subjekt" (Crary, p. 14), som ifølge bl.a. synshistorikeren Jonathan Crary indleder moderniteten. ${ }^{3}$ Panoramaet er det første eksempel på et visuelt kulturindustrielt synsmedie, og repræsenterer dermed en markant udvikling fra det umedierede overblik. Panoramaet repræsenterer en ny synsmodus, som afspejler og får indflydelse på en lang række af de samfunds- og mentalitetsændringer, der følger efter Den franske Revolution og tager fart i 1800-tallet. Samtidig markerer panoramaet den historiske tærskel til den medievirkelighed, der omslutter os i dag.

\section{I}

Ferragus indledes med 4 siders udførlige beskrivelser og overvejelser over det parisiske byrum, og hvordan byen påvirker menneskene og omvendt: „Gaderne har menneskelige egenskaber og de indprenter med deres fysiognomi visse ideer i os mod hvilke vi er forsvarsløse" (Balzac, V, p. 791). Byen antropomorfiseres samtidig med, at byboeren urbaniseres, og dette chiastiske mix af urbaniseret menneske og menneskeliggiort by krydres desuden rigeligt med monstrøse og uhyrlige elementer til at anskueliggøre, at der bestemt ikke er tale om nogen forsonende og overskuelig syntese, men snarere om en stadig stridende dialektik uden udsigt til forløsning. ${ }^{4}$ Romanens indledende, altseende fortæller afløses gradvist af flanørens mobile, urbane optik, og romanen tematiserer langt hen ad vejen, hvordan overblikket over plottet og kontrollen med byens sammenvævede topografi viser sig at være umulig for såvel fortæller som for romanens detektiviske hovedpersoner.

Kort sagt er Ferragus den moderne bevægelige, sværmende og topografisk sammenvævede bys tale: „Artikulationerne knager umærkeligt, bevægelsen kommunikerer sig, gaden taler", 5 (Balzac, V, p. 794). Romanen opstår direkte som et produkt af denne bevægelse, der gør byen besværlig at klassificere og overskue, og som transformerer byen som sted til byen som roman: „de hundrede tusinde romaners by" (Balzac, V, p. 795).

Dette bliver helt tydeligt, hvor plottet vokser frem af de parisiske gader, hvor byens bevægelse og gadernes tale opfattes af den opmærksomme flanør-fortæller, som tilfældigt krydser denne instans af sammenvævet tid og sted. I et langt afsnit, hvor syntaksen er ligeså labyrintisk som de parisiske gader i det skumle kvarter, fremlægges, hvordan romanens kvindelige hovedperson befinder sig på det forkerte sted på det forkerte tidspunkt i forhold til, hvor hun hører hjemme. Hun ses oven i købet af den forkerte person, hvilket relateres til, hvor han stammer fra i byen. Samtidig stedsbestemmes handlingen i forhold til resten af Paris og den tidsbestemmes i forhold til det tidspunkt, romanen er skrevet. Alt er således vævet ind $i$ hinanden, både syntaktisk, topografisk og temporalt, og plottet, som resten af romanen drejer sig om, udtrykkes præcist i den sætning, der afslutter passagen og artikulerer dens sammenvævning af tider og steder: "Hehde, i dette smuds, på dette tidspunkt!" (Balzac, V, p. 797).

Resten af fortællingen handler om, hvordan de forskellige protagonister forgæves forsøger at udrede og kontrollere dette plot af sammenvævet, parisisk tid og sted. ${ }^{6}$ 
I Le père Goriot indleder en forfatter-agtig fortæller med at tvivle på, om romanen overhovedet kan læses. Først slår han fast, at romanen formodentlig hverken kan forstås eller vil blive værdsat uden for Paris, hvorefter han længere nede i samme afsnit tager forbehold for en parisisk læsning af romanen - en læsning som blot vil fortære romanen uden anfægtelser. Lidt senere ser han denne ulæselighed som en egenskab ved Paris selv - en egenskab som selvfølgelig må smitte af på romanèn om Paris:

Men Paris er et sandt ocean. Om De lodder det nok så meget, så vil De aldrig blive klar over dybden. Gå det igennem, beskriv det! Med hvilken omhu De end giver Dem til at gå det igennem, at beskrive det; hvor talrige og interesserede dette havs opdagelsesrejsende end er, så vil man dog altid kunne finde jomfruelige og ukendte steder, blomster, perler, monstre, et eller andet uhørt, glemt af de litterære dykkere. Maison Vauquer er en af disse kuriøse monstrøsiteter. (Balzac, III, p. 59)

Denne ulæselighed inkorporeres som et deskriptivt træk i romanen, som fortsætter med at beskrive pensionen, Maison Vauquer. Men fortælleren mister det altseende, perspektiviske overblik, som fortællingen indledes med, undervejs i sin beskrivelse. Allerede $\mathrm{i}$ den indledende beskrivelse af byen, kvarteret og gaden, hvor pensionen ligger, får vi at vide, at en mulig iagttager og fortællersubstitut er faret vild („Un Parisien égaré..." Balzac, III, p. 51) i dette kvarter. Kvarteret er det mest horrible og mest ukendte i byen, men på trods - eller måske netop på grund - af denne monstrøsitet danner kvarteret en mørk og dyster ramme for fortællingen, der fører os helt ned i katakomberne og på denne måde henviser til det, der ligger under og undergraver det perspektiviske overblik. Efter at have beskrevet denne ramme knyttes fortællersynsvinkelen i store træk til hovedpersonen Rastignacs navigering igennem den parisiske mudderpøl, hvor han med skiftende og stadig større held forsøger at stifte alliancer til brug i sin bestræbelse på social opstigning på bekostning af sin uskyldige dydighed. Mudderet, skidtet og sliddet bliver undervejs til et ledemotiv i.fortællingen som det, der altid mærker personerne og tingene. Intet er længere rent og klart; der kommer bogstaveligt talt skidt i repræsentationen og det perspektiviske blik på byen.

Undervejs gennem romanen fungerer stilistiske figurer som paradoks, oxymoron og chiasme som yderligere nedbrydninger af et centralperspektivisk, enhedsligt perspektiv til fordel for flerdimensionale, man kunne næsten fristes til at sige binokulære perspektiver, med blik for hvordan to forskellige ordener folder sig ind i hinanden og udfolder flerdimensionalitet. Enten demonstrerer chiasmen via sit dobbeltblik forsøg på at bruge sproget til at skjule, 7 eller også viser den hvordan omgivelserne og personerne er foldet ind $\mathrm{i}$ hinanden og gensidigt udfolder eller forklarer hinanden. Specielt pensionatsværtinden i Maison Vauquer, Mme Vauquer, er et godt eksempel på dette. I en passage sammenlignes hun med sit pensionat, som hun både er „i harmoni med", "sammenfatter", "annoncerer" og "forklarer". Passagen kulminerer i chiasmen „enfin toute sa personne explique la pension, comme la pension implique sa personne"8 (Balzac, III, p. 54), hvor Mme Vauquer i en kompleks figur udfolder det, hun er indfoldet $\mathrm{i}$.

Med andre ord bryder klassifikationerne, kategorierne og det perspektivisk ordnende overblik sammen i mødet med den moderne storby, som Paris er i færd med at udvikle sig til. Og det er fra dette sammenbrud af faste kategorier og stabilitet, at den balzacske realisme og narration spirer. ${ }^{9}$ Først når den perspektiviske fortællers overblik brydes eller viser sig utilstrækkeligt i mødet med et mysterium af sammenvævet topografi og urbaniserede personer, kan narrationen begynde. Først når fortællerblikket føres videre af en person nede $\mathrm{i}$ den parisiske sump, som for eksempel Rastignac i Le père Goriot, udvikler narrationen sig: „Uden hans videbegærlige iagttagelser (...) ville denne fortælling ikke være farvet af den sande tone og stil, som den uden tvivl skylder han's kløgtighed og begær efter at gennemtrænge mysterierne..." (Balzac, III, p. 56). ${ }^{10}$

Begge disse Parisromaner indleder i øvrigt den periode, hvor Balzac samler og ordner sine i romaner i værket La Comédie humaine vha. teknikken med de genkommende personer. ${ }^{11}$ En tek- 
nik der bevirker, at romanernes enhedslige værkkarakter ophæves og de enkelte romaner indsættes i et system, hvor de eksplicit spejler, reflekterer og kommenterer hinanden. Hele værket med dets knap 100 romaner bliver dermed del af det samme billede, hvor den enkelte romans perspektiver og forsvindingspunkter efterhånden kittes sammen til et større og mere omfattende billede. Et panorama over 1800-tallets Paris og Frankrig, som samtidig kan anskues fra romanernes utallige vinkler. ${ }^{12}$

Både Le père Goriot og Ferragus monterer et panoramisk blik på Paris som deres slutning. Hen mod slutningen ${ }^{13}$ af Ferragus tager Jules Desmarets op på kirkegården Père Lachaise for at se til sin kones grav. Først betragter han kirkegården som en død repræsentation af det levende Paris, hvorefter han hæver blikket og betragter det virkelige Paris som baggrund i et panoramisk skue:

Det er en infam komedie! Det er atter hele Paris med dens gader, dens skilte, dens gøremål, dens palæer; men set med en teaterkikkerts groft slebne linser, et mikroskopisk Paris reduceret til de små dimensioner hos skyggerne, larverne, de døde, en human genre som intet stort har længere foruden sin forfængelige tomhed. Derefter lagde Jules mærke til, det virkelige Paris ved sine fødder, i den lange Seinẹdal, mellem skrænterne i Vaugirard, i Meudon, Belleville og Montmartre, indhyllet [enveloppée] i et blåligt slør produceret af dens røg, og som solens lys gjorde gennemsigtig. Han omfavnede med et stjålent øjekast [embrassa d'un coup d'oeil furtif] disse fyrre tusind huse, og sagde mens han pegede på rummet indbefattet [l'espace compris] mellem Vendômesøjlen og Invalidekirkens gyldne kuppel: - Hun er blevet taget fra mig dér ved hjælp af denne verdens ødelæggende nysgerrighed, som har travlt og trænges mellem hinanden blot for at trænges og have travlt. (Balzac, V, p. 898)

Det samme blik afslutter Le père Goriot, hvori panorama-temaet desuden optræder flere gange på centrale steder (cf. Pold, 1994, pp. 111-113). Rastignac er oppe på Père Lachaise, hvor han har begravet faderfiguren, Goriot:

Da Rastignac var blevet alene, gik han nogle skridt højere op på kirkegården og så Paris, som lå og bugtede sig [tortueusement couché] langs
Seinens to bredder, hvor lysene begyndte at skinne. Hans øjne fæstnede sig næsten begærligt mellem søjlen på Vendôme pladsen og kuplen på Invalidekirken [entre la colonne de la place Vendôme et le dôme des Invalides], der, hvor denne skønne verden han havde villet trænge ind $i$ levede. Han kastede et blik på denne summende bikube, som om han på forhånd sugede dens honning til sig, og sagde disse storslåede ord: $-\mathrm{Nu}$ er det os to!

Og som den første udfordring mod samfundet, gik Rastignac til middag hos madame de Nucingen. (Balzac, III, p. 290)

Byen beskrives i begge blik som et fantasmagorisk, forførende stemningsbillede fremkaldt af forskellige lyseffekter. Samtidig er byen beskrevet som et rum, der er lukket om sig selv og dermed lukket for det centralperspektiviske blik. I Ferragus danner sollysets spillen i røgen, der indhylder [enveloppée] byen, et luftperspektiv ${ }^{14}$ på byen, som er indesluttet mellem de fire skrænter Vaugirard, Meudon, Belleville og Montmartre. Byen og dens rum forskønnes desuden via sfumato effekten (se note 14), som giver den atmosfære og gør den på én gang forførende og illusorisk. Jules „omfavnede med et stjålent øjekast” byens fyrre tusinde huse og peger på „rummet indbefattet” mellem Vendôme pladsen og Invalide kirken, mens han sukker over den moderne by som har taget hans kone fra ham. - En sukken som til overflod er udformet som en chiasme, der illustrerer Jules' distancerede resignation over sin magtesløshed. Hans resignation bliver yderligere iscenesat af panoramabilledets nærværende fravær; dets dobbelthed af at være både sted og ikke-sted eller en nærværende repræsentation (udgjort af kirkegårdens døde reproduktion) af det fraværende, levende og begærede Paris, som det ikke lykkedes Jules eller nogen anden at beherske eller overskue i romanen. ${ }^{15}$ Panorama-billedèt er på én gang sted og ikke-sted, Paris og „Paris”, og således udtrykker det præcist byens nye ustabile karakter, hvordan dens topografi fordobles $i$ en massebevidsthed.

I Le père Goriot opbygges det fantasmagoriske stemningsbillede ved byens lys, som begynder at stråle i skumringen, og byen ses dermed i skumringens overgang fra dagslysets naturlige synlighed til nattens kunstigt oplyste synliggjorthed; illumination 
।

på grænsen til fantasmagori. ${ }^{16}$ Byen ligger som en kurtisane og bugter sig langs med Seinens bredder og Rastignac kigger „næsten begærligt" på det rum, der udgøres af den rige by og beskrives som lukket om sig selv i chiasmen: „entre la colonne de la place Vendôme et le dôme des Invalides". I modsætning til Jules bruger Rastignac panoramaperspektivet til at udfordre den tillukkede, rige by begærligt. Han forlader det panoramiske perspektiv og går energisk ned i byen igen for at kæmpe videre med den, og her slutter romanen. 17

Jules erkender således resigneret panoramaets simulationsagtige karakter, som forhindrer samtidigheden af et fuldgyldigt nærvær og et kontrollerende, agerende overblik over byen. Rastignac derimod fuldbyrder sin dannelse gennem panoramaet som en moderne romanhelt, der er i stand til at begå sig i en moderne urban virkelighed med dens simulationer og mere eller mindre løgnagtige repræsentationer. ${ }^{18}$ Eller også forføres han blot af den panoramiske simulations storslåethed, og lokkes ned i den af fantasmagorier fortryllede by, som han lige har forbandet. Begge læsninger ligger som potentielle muligheder og formodentlig udelukker de heller ikke hinanden helt, men peger begge påkarakteristiske træk ved den moderne helt og hans dannelse. Dannelsen kan ikke længere bringes på en sikker formel, men består i en evne til at erkende - og manøvrere i - den nye, fremvoksende masse- og medievirkelighed. Eftersom byen ikke udelukkende er et sted, kan man heller ikke overskue den fra et sted, hvilket Balzac demonstrerer igennem panoramaets' massemedieperspektiv.

Hvis byen ikke blot er et sted, hvad er den så? Hvad transformerer romanerne byen til gennem den mobile optik (flanør-perspektivet) og beskrivelsen af byens ustabile og dynamiske virkelighed, gennemsyret af bevidsthed om tegngivning og mere eller mindre løgnagtig repræsentation eller simulation? Michel de Certeau skelner i sin analyse af dagligdagens retorik, L'invention du quotidien, mellem lieu og espace; sted og rum. Ingen af de to former optræder formentlig nogensinde rent, men skal snarere ses som forskellige modi i rumbeskrivelse og rumopfattelse. Lieu er det ordnede sted, hvis elementer optræder ved siden af hinanden, hver i deres eget, specifikke og særegne ['propre'] sted som de definerer. Et lieu er således en øjeblikskonfiguration af positioner, som indbéfatter en angivelse af stabilitet. ${ }^{19}$ Espace er derimod „en krydsning af mobiler", som er animeret af den helhed af bevægelser, der udfolder sig deri. ${ }^{20}$ Espace er det fortalte, temporaliserede, konfliktfyldte, aktualiserede eller vilkårliggjorte [circonstancient] og polyvalente, som i modsætning til stedet ikke er hverken entydigt eller stabilt. Espace er kort sagt lieu i praksis. ${ }^{21}$ Certeau skelner også mellem to forskellige spatiale beskrivelser, kortet over for rutebeskrivelsen som ækvivalerer de to former. Kortet er beregnet på henholdsvis at se og etablere et overskueligt tableau, mens rutebeskrivelsen er beregnet på at navigere $\mathrm{i}$ rummet og dermed organisere et rum for bevægelse.

De to romaner beskriver en sådan transformation af Paris fra lieu til espace. Overblikket bliver nedbrudt og demonstreret som utilstrækkeligt, mens byen bliver praktiseret i romanerne og indskrives som både passiv scenografi og aktiv scenograf, der via sine gader og kvarterer danner baggrund for personerne samt styrer dem rundt, arrangerer tilfældige møder og tilrettelægger de mysterier, som plottene er opbygget af. ${ }^{22}$ Henri Mitterand slutter sin analyse af Ferragus' brug af det parisiske rum med at konkludere, at „Romanen, især siden Balzac, narrativiserer rummet i ordets præcise betydning" (Mitterand, p. 17). Denne narrativisering eller transformation af byens lieu til espace får sit udtryk i panorama-mediet gennem de afsluttende panoramablik på byen.

III

Panoramaet præsenterer en ny tids blik. Et blik, der som hos Balzac tager højde for at byen er under forandring. Et blik der markerer begyndelsen på den udvikling fra fysisk urbanisering til médiets globale urbanisering, ${ }^{23}$ den globale storby, som vi alle bor og færdes i med vores moderne telematiske synsmaskiner, der med større og større gennemslagskraft forener verden gen- 
nem deres sammenkoblinger af infrastruktur og simulerede billeder.

I 1787 patenterede Robert Barker en opfindelse han kaldte "La Nature à Coup d' Eil ", som hurtigt skiftede navn til panorama. ${ }^{24}$ Det første parisiske panorama blev bygget i 1799 og i løbet af de næste fem år blev der åbnet fire mere, deraf to pà Boulevard de Montmartre, der gav navn til Paris' første passage: Passage des Panoramas. Samtidig udløste panoramaernes succes i det parisiske forlystelsesliv en veritabel dille, hvor caféer indrettede små panoramaer, hjemmene fik panorama-tapeter og sproget invaderedes af panorama-udtryk, som det bl.a. beskrives i Le père Goriot:

Den nylige opfindelse af dioramaet, som frembragte en optisk illusion i endnu højere grad end i panoramaerne, havde i nogle maleres atelierer indført en spøg med at tale rama; en slags last som en ung maler, der boede i pension Vauquer, havde indført dér. ${ }^{25}$

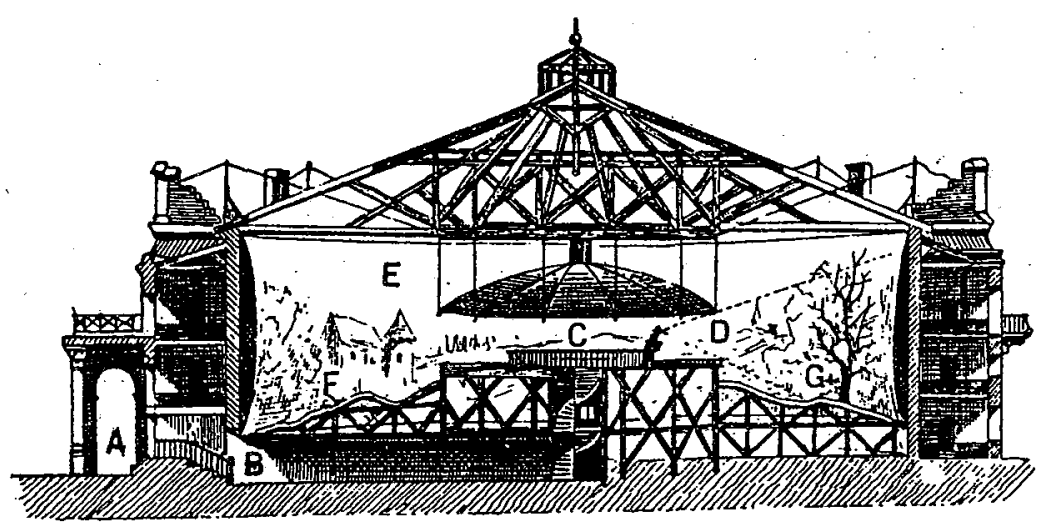

Tværsnit af et Panorama:

A: Indgang og kasse

B: Mørkelagt gang

C: Tilskuerplatform med sejl over

D: Tilskuerens synsvinkel

E: Opspændt lærredsvæg hele vejen rundt

F: Plastisk udformet forgrund (Faux terrain)

G: Genstande på lærredsvæggen malet på trompe-l'oeil maner

(Illustrationen er fra Sehsucht, p.125)
Et panorama består af en rotunde med et maleri ophængt hele vejen rundt langs væggen $(E)$. I midten af rotunden er der en tilskuerplatform (C) med en baldakin foroven og en afskærmning forneden, som fórhindrer tilskuerne $\mathrm{i}$ at kigge ud over billedets kant (D). Mellem tilskuerne og den malede lærredsvæg udvikledes et plastisk faux terrain (F), som umærkeligt går over i den malede lærredsvæg via trompe l'œil effekter (G). Adgang til tilskuerplatformen sker gennem kassen (A) og videre gennem en underjordisk, mørk gang (B), hvor tilskuernes øjne vænnes til mørke, før de.stiger op på tilskuerplatformen. ${ }^{26}$

Rotundebygningen er indrettet med en avanceret tagkonstruktion, der forsyner bygningen med et klart, naturligt ovenlys, som falder på billedet, mens tilskuerplatformen ligger afskærmet i mørke under baldakinen. Billedet ligger badet i lys, der reflekteres mod tilskuerne, som betragter det fra mørket, hvilket gav en hidtil uset illusorisk effekt, hvor billedets lys er enerådende og indhylder tilskuerplatformens mørke. En effekt, der siden er anvendt $i$ andre visuelle medier med egen arkitektur, som f.eks. biografen. ${ }^{27}$

Samtidig er panoramaet, som Stephan Oettermann skriver, en „kunstform, hvor billede og udstillingsrum er uadskilleligt sammensnoet" (Oettermann, p. 42). Kunstværkets rum og udstillingsrummet er uadskilleligt som senere $\mathrm{i}$ installationskunsten, og lyset manipuleres via tagkonstruktionen og baldakinen til at arbejde sammen med kunstværkets lys. Men eftersom man stadig var afhængig af naturligt lys, gav det nogle problemer med gråvejrslys på et solskinsbillede eller endnu værre; forkerte skygger. Af kunstneriske grunde valgte man ofte en morgen eller aftensol, da den gav større stemningseffekt med sit differentierede lys end middagslysets skarpe enshed og korte skygger. Omvendt kunne man ikke tillade sig at bruge for megen skyggeeffekt, når man skulle lave dybdevirkning, idet panoramaets illusion bliver ødelagt, hvis det udefrakommende lys adskiller sig fra maleriets lys. Man forsøgte på forskellig måde at tage højde for disse problemer bl.a. ved brug af luftperspektiv, men de var i bund og grund uløselige, så længe man benyttede naturligt lys. 
Denne totale sammenarbejdning af værkets rum og udstillingsrummet, af artikuleret rum og artikulationsrum, sammen med den raffinerede brug af lyset, der reflekteres fra billedet mod tilskuerplatformens mørke, bruges effektivt og nyskabende i panoramaet til at skabe en effekt, der ikke kan omfattes af traditionelle repræsentationskategorier, men må karakteriseres som værende på tærsklen mellem repræsentation og simulation. Tilskuerne var fuldstændig fanget af panoramaets illusionen og havde ingen muligheder for at lade blikket vandre ud over rammerne og sammenligne med virkeligheden. Panoramaet er således det første billede, der fuldstændig fanger tilskuerens blik; det er på paradoksal vis en udsigtsbygning uden synlige vinduer. Som total illusorisk realitet i hele synsfeltets $360^{\circ}$ peger panoramaet direkte frem mod vor tids og fremtidens immersionsmedier samlet i forestillingen om Virtual Reality. Panoramaet kan kort sagt karakteriseres som en synsmaskine, der bruger en sammensnoning af et virkeligt rum og et malet rum til at transportere tilskueren et helt tredje sted hen. Gennem panoramaets totale og ikke kun i sin samtid - overvældende virkning transporteres publikum ind i et virtuelt, fiktivt medierum.

Norbert Bolz fremhæver overgangen fra mimesis til projektion som skelsættende for overgangen mellem efterligning og fremstilling i sin bog, Am Ende der Gutenberg-Galaxis. Han konkluderer, at „projektion betyder fremfor alt [også]: rumlig-tidslig fremstilling [Darstellung], som flytter betragteren ind i den æstetiske produktion" (Bolz, p. 160), hvilket opfyldes med panoramaet, i hvert fald hvad angår den rumlige dimension. ${ }^{28}$ Til gengæld opfylder panoramaet knap betingelserne for at tilhøre det „immaterielles æstetik, der konsekvent fjerner sig fra pigmentet og først kommer til sin fulde ret i computerbilledskærmenens pixelkonfigurationer" (Bolz, p. 160), selvom panoramaets brug af lyseffekter og forsøg med at styre lyset markerer et første skridt $i$ denne retning. Som emblem for startpunktet på denne udvikling ser Bolz overgangen fra maleriets lærred til filmlærredet, men han kunne også have fundet et tidligere eksempel på denne udvikling i dioramaets overgang frà maleriets lærred til gennemsigtige plader. ${ }^{29}$ Ikke desto mindre gør panoramaets brug af rum- met og lyset det til et medie, der i sin konstruktion spiller på en oscilleren mellem maleri og arkitektur; mellem repræsentation og simulation. Denne oscilleren mellem repræsentation og simulation baner vej for, hvad Don Slater i sin diskussion af det tidlige fotografi kalder en „ontologisk forvirring” (Slater, p. 233); et karaktertræk der betyder, at panoramaet som billedmedie adskiller sig fra tidligere billedformer og peger frem mod senere billedmedier og i sidste eride en medievirkelighed, hvor selve virkelighedsbegrebet og dermed også erkendelsen af virkeligheden bliver ramt af samme 'ontologiske forvirring', og derfor på paradoksal vis må benytte sig af mediets optik. ${ }^{30}$

IV

Panoramaets virkning kan man selvfølgelig stadig selv overbevise sig om ved at besøge et af de forholdsvis få bevarede panoramaer i verden, selvom man nok kan have svært ved at rekonstruere 1800-tallets begejstring med en post-moderne; simulations- og medievant perception. Selv har jeg besøgt Ludek Marolds panorama over Hussitternedslagtningen ved Lipany i en forlystelsespark i udkanten af Prag, ${ }^{31}$ og selvom jeg må betragtes som miljøskadet, så var det en overrumplende virkningsfuld oplevelse. Efter kort tids tilvænning til lyset, fik jeg et stærkt indtryk af, at rotundens konkrete, fysiske rum transformeredes og transcenderedes gennem samspillet med det repræsenterede rum, og det skabte en stærk effekt af et simuleret, panoramisk rum. Kort sagt virkede trompe l'œil.effekterne og samspillet mellem faux terrain og lærredsvæggen overbevisende. Man kunne både lade sig forføre af virkningen og samtidig skelne trompe l'œil effekterne, og jeg fik en klar illusion af at stå midt på en stivnet slagmark samtidig med, at jeg ikke et øjeblik var i tvivl om, at det var en simulation.

Panoramaet er på denne måde en form for narrativiseret vision, hvor man som tilskuer står midt i en handling, en begivenhed der blot er stivnet et øjeblik til en scene, hvor krigernes våben er standset lige før gennemboringen af modștanderen. Man fragtes som tilskuer ind midt $i$ handlingens stivnede men dyna- 
miske rum, og panoramaer viste ofte begivenheder, der som en narrations paroxystiske klimaks både har en forhistorie og en efterhistorie. Nøjagtig som i Le père Goriot, hvor panorama-slutningen både peger tilbage på hele romanens handlingsrum og frem mod nye romaner.

Da jeg kom ud, havde jeg samme fornemmelse som efter en god eftermiddagsforestilling, hvor man, når man kommer ud i dagslyset igen, misser lidt med øjnene, mens man justerer sin perception tilbage til den virkelige gade, man nu står på, samtidig med at simulationen og handlingsbillederne bliver hængende i baghovedet.

Stephan Oettermann har naturligvis også besøgt et panorama. Han beskriver, hvordan man fra den lyse gade og efter at have passeret gennem den mørke underjordiske gang træder op i panoramaet og som med et trylleslag befinder sig et andet sted. „Efter få minutter når erindringen om det udenfor blegner, og øjnene har vænnet sig til det lette skumringslys, tror man fuldstændig på, at man fra en pavillon på en lille høj kigger ud i det vide landskab og mod det blånende klare fjerne." (Oettermann, p. 43). Oettermann citerer også flere rapporter fra samtidige besøg i panoramaet, bl.a. Chateubriands udbrud ved gensynet at Jerusalem $i$ et parisisk panorama:

Vi har i Paris set panoramaer af Jerusalem og Athen og jeg genkendte ved første øjekast alle monumenterne, alle stederne, om det så var det lille kammer i den Hellige Frelsers Kloster, hvor jeg havde boet. Aldrig har nogen rejsende været udsat for en så hård prøvelse. Jeg havde aldrig forventet, at man skulle transportere Jerusalem og Athen til Paris. (Oettermann, p. 122) ${ }^{32}$

Som citatet viser bliver panoramaet også i samtiden opfattet som en maskine for virtuel transport af blikket. Oettermann citerer Hegel, der efter at have set Alaux' parisiske neorama ${ }^{33}$ udbryder, at nu behøver man ikke længere at rejse til Rom for at tilbede paven. Men parallelt med at panoramaet via sin virtuelle transport af blikket på denne måde overflødiggør den besværlige fysiske rejse opstår en ny folkelig rejsetrang i kølvandet på jernbanens udbredelse. Rejsen bliver meget hurtigere, billigere og langt mere komfortabel, hvilket fører til turismens opståen. ${ }^{34}$ Dolf Sternberger beskriver direkte den nye mobilitet med jernbanen som en panoramatisering af verden, hvor hele verden opfattes som et panorama. Turisten ser verden som et panorama fra sin komfortable togkupé, og hele verden forvandles gradvist til turist-sights hvilket får Sternberger til at udbryde kulturpessimistisk: „Udsigten fra de europæiske vinduer har fuldstændig tabt dybdedimensionen og er udelukkende blevet del af en og samme panoramaverden, som strækker sig hele vejen rundt og overalt kun er bemalede flader. ${ }^{\prime 35}$

Hvis vi skal vende tilbage til de Certeaus begreber om lieu og espace, kunne man let komme til at se en historisk udvikling, hvor stedet mister sin selvberoenhed som lieu og transformeres i retning af den dynamiske rumopfattelse, espace, som for de Certeau også står for den mest beboelige. Men den parallelle udvikling af jernbanen og turismen, panoramaets virtuelle transport og panoramiseringen af verden viser, at det ikke er helt så enkelt. Både den virtuelle og den virkelige transport har sin pris og begge dele skaber såvel nye friheder som nye restriktioner, hvilket dog ikke betyder, at der ingen udvikling sker.

\section{V}

Panoramaet bliver en synsmaskine, der viser og 'producerer' en ny opfattelse af tid og rum, som af bl.a. Bolz og Oettermann sammenlignes med strukturer i det borgerlige, kapitalistiske samfund og ideologi.

Det centralperspektiviske billede har indlagt en fast læseretning organiseret mod et unikt forsvindingspunkt og set fra ét ideelt, statisk punkt gennem en fast synsvinkel. Selvom et centralperspektivisk billede udmærket kan ses fra andre positioner end den ideelle, ændrer det ikke på den i konstruktionen indskrevede læseretning. Oettermann konkluderer at: „Centralperspektivisk konstruerede billeder er eksklusive billeder såvidt, som de udelukker alle andre personer fra betragtningen end én priviligeret." (Oettermann, p. 26). Ofte er den centralperspekti- 
viske konstruktion tilmed udnyttet til at fremstille allegoriske billeder med en fast, monistisk læseretning orienteret mod fyrsten ${ }^{36}$ eller Gud. ${ }^{37}$ I panoramaet afløses dette monistiske centralperspektiv af et stereoskopisk polyperspektiv, hvor det todimensionale afløses af panoramaets tredimensionale rum, og forsvindingspunktet afløses af horisontlinjen med dens uendelige antal forsvindingspunkter. Parallelt med det uendelige antal forsvindingspunkter $\mathrm{i}$ horisontlinjen afløses det statiske, unikke, ideelle betragterpunkt med et, i princippet, uendeligt antal betragterpunkter og synsvinkler, der dog i praksis var begrænset til de op til 150 personer, som kunne være på tilskuerplatformen. Panoramaet var derfor helt konkret samt i formel forstand et nyt massemedie rettet mod det nye massepublikum i 1800-tallets storbyer; en „demokratisering af perspektivet" (ibid.) eller en udvikling fra et enhedsperspektiv til et masseperspektiv, hvor den enkelte tilskuer kan erkende sig sèlv som del af en masse og som ude af stand til at overskue hele billedet i dets $360^{\circ}$. Det enkelte individ erfarer således som tilskuer i panoramaet, at grænserne ikke længere udgøres af en fyrstes eller en Guds centralperspektiviske organisering af verden, men derimod af individets eget perspektivs begrænsninger som kun en brøkdel af massens fulde perspektiv. Desuden medfører det panoramiske blik, som jeg har været inde på, en immersion i billedet, en „,væren i billedet“ (Bolz, p. 103), hvor man ikke kan bryde ud. I modsætning til indrammede billeder har man intet stand punkt udenfor, hvorfra man kan betragte, og man kan ikke etablere en kritisk distance til billedet. Bolz sammenligner direkte med den borgerlige friheds begrænsninger: „Den al-sigtbare [allsichtige] moderne borger kan ikke se, at han ikke kan se det, han ikke kan se." (Ibid.). Befrielsen af synsvinkelen fra det monistiske perspektiv medfører en ny form for fangenskab, som panoramaet indlærer, afspejler eller reflekterer over. ${ }^{38}$

Samtidig med denne demokratisering af perspektivet fulgte med panoramaet en ændring af udstillingspraksissen, der medførte nye former for motiver. I modsætning til tidligere fyrstelige samlinger af malerier med allegoriske motiver, som kun var afkodelige for dannede kendere, var der nu tale om billeder, som var tilgængelige for en betalende offentlighed. Dette nye massepublikum krævede realistiske landskabsfremstillinger med encyklopædisk nøjagtighed, „hvor økonomernes blik kunne skoles“ (Oettermann, p ؛ 26.), ${ }^{39}$ eller „realpolitiske begivenheder som slag, belejringer etc., som interesserede avislæseren“ (ibid.).

Både i panoramaet og under togrejsen rettes blikket mod horisonten, ${ }^{40}$ og Oettermann beskriver, hvordan panoramablikket opstår gennem en 'opdagelse' eller en ny erfaring af horisonten. Kunstnere som Goethe og Casper David Friedrich førte i slutningen af 1700-tallet an i en bestræbelse på at bringe blikket op, hvor det var frit og kun begrænset af horisonten, og i kølvandet blev det moderne at bygge udsigtstårne og bestige bjerge. Samtidig blev ballonopstigninger til en grille anført af Montgolfierbrødrenes opfindelse af varmluftsballonen i 1783 og senere Nadars luftfotografier. ${ }^{41}$ Oettermann beskriver horisonterfaringen som en generel tankefigur for borgerligheden, en ny slags grænsetænkning, hvor grænsen ikke længere er absolut, men noget der kan forskydes eller udvides gennem rejse og udforskning. Grænsen bliver metaforisk som horisont, og Oettermann sammenligner direkte ballonfarten med den borgerlige ekspansionisme, grænseløshed og utopiske håb: „De håb, som i den grænseoverskridende ballon fandt deres billede, var, trods deres også alment menneskelige udtryk, af eminent politisk natur." (Oettermann, p. 15)

\section{VI}

1800-tallet var panoramaets århundrede i mere end en forstand. Et århundrede, hvor medievirkeligheden efterhånden vokser frem af byen, men hvor den stadig ligner og er realistisk afbildet som i panoramaet. Et århundrede, hvor det virtuelle rum stadig afhang og skabtes af et virkeligt rum, men hvor den umiddelbare forbindelse mellem iagttageren og rummet blev mere og mere problematisk. Jonathan Crary opsummerer forbindelserne mellem modernitetens frembrud og det tidlige 1800-tals populærkulturelle synsmaskiners "separation af sanserne“ $i$ en polemik mod den modernitetsteori, der indstifter et synshistorisk brud 
med det senere modernistiske maleri og kunst. 42 Han beskriver hvordan synsmaskiner som stereoskopet og panoramaet førte til tabet af det nære rum og den taktile referentiabilitet til omverden:

Tabet af berøring som en konceptuel komponent ved synet betød frigø relsen af øjet fra det netværk af referentialitet som var inkarneret i taktiliteten og dens subjektive relation til det opfattede rum. Denne autonomisering af synssansen, som dukkede op indenfor mange forskellige domæner, var en historisk betingelse for opbygningen af en iagttager, som var indrettet på det 'spektakulære' forbrugsmønster. Den empiriske isolation af synssansen førte ikke kun til dens kvantificering og homogenisering men den muliggjorde også at de nye synsobjekter (hvadenten det var varer, fotografier eller selve perceptionsakten) antog en mystificeret og abstrakt identitet, afsondret fra enhver forbindelse til iagttagerens position indenfor et kognitivt forenet felt. (Crary, p. 19)

Hos Balzac er det tydeligt, at han havde et godt øje for den nye 'spektakulære' iagttager i det kvantificerede varesamfund, som bryder frem. Samtidig transformeres den virkelige by gennem den narrativiserede by og hele denne (litteratur-)historiske udvikling får sit udtryk i panorama-mediet hos Balzac såvel som i Paris og andre af verdens metropoler. Men udviklingen sluttede ikke med panoramaet. Gennem århundredet ledte den fysiologiske forskning i synet til nye og stadig mere raffinerede synsmaskiner. Panoramaet udvikledes op igennem århundredet gennem talrige nye opfindelser, patenter og opfindsomme navne på de tredimensionale, fantasmagoriske synsmaskiner. Med dioramaet eksperimenterede man med projektion og (begrænset) bevægelse for med lysets hjælp at repræsentere tidens gang, mens man med phanakistiskopet og zootropen arbejdede med direkte at fremstille fri bevægelse som senere $i$ filmen. For blot at antyde denne udvikling vil jeg citere Benjamins opremsning fra Das Passagen-Werk:

Der fandtes Panoramaer, Dioramaer, Kosmoramaer, diaphanoramaer, Navaloramer, Pleoramaer (...), Fantoskoper, fantasma-parastasier, Expériences fantasmagoriques et fantasmaparastatiques, maleriske rejser i stuen, georamaer, optiske pittoresker, cinéoramaer, phanoramaer, stereoramaer, cykloramaer, dramatiske panoramaer. (p. 655)

Panoramaets svanesang er på flere måder repræsenteret af Grimoin-Sansons utrolige cinéorama på verdensudstillingen i Paris i år 1900. Dette filmiske panorama var optaget med 10 filmkameraer spændt under en ballon, som lettede fra Paris og blev fremvist $\mathrm{i}$ en panoramarotunde af 10 fremvisere. Publikum strømmede til for at få oplevelsen af at lette med ballon, men denne form for fremvisning blev dog ikke en langvarig succes, da det var for uoverskueligt at præsentere en egentlig handling i dette format. Publikum gik til filmen.

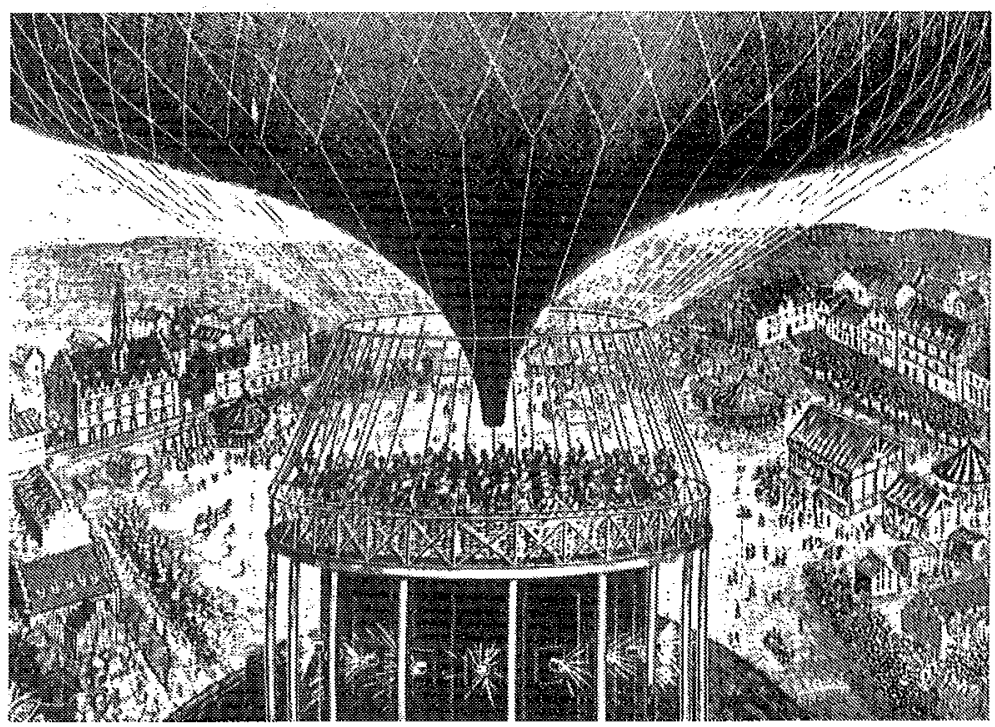

Grimmoin-Sansons Cinéorama.

Samtidig var medieteknologien og reproduktionsteknikkerne også efterhånden blevet forbedret så meget, at de fik et selvstændigt udtryk, 43 hvor fremstillingsaspektet, simulationen, mere og mere overskyggede efterligningsaspektet, repræsentationen, eller hvor der sker en overgang fra synet til synliggørelsen gennem synsmaskinerne. ${ }^{44}$ Dermed sker et skred fra en fremstillings- 
form, man kunne kalde realistisk, til noget, man med Virilio kunne kalde hyperrealisme, hvor der er latente billeder overalt. Billeder som ikke kræver faste udstillingsrum, som potentielt ikke har nogen fysisk form, og derfor ikke er umiddelbart synlige for det menneskelige øje.

Derfor er det en fejltagelse, om end en af de mere interessante, når Jules Vernes unge digterprotagonist afslutter romanen Paris $i$ det 20. århundrede med et panoramisk vue, der tydeligvis citerer Balzac og slutter med digterprotagonisten Michels ønske om at destruere dette panoramiske Paris. Michel har på sin vej op af kirkegården bl.a. passeret Balzac og andre 1800-tals forfatteres grave. Han er nået op på toppen af kirkegården og ser Paris „udbredt for hans blik":

Byens hundredetusind huse klumpede sig sammen under de titusinder af fabriksskorstenes røgfaner. Nærmest og nederst i synsfeltet havde han den lavere liggende del af kirkegården. Iagttaget herfra lignede de kostbare gravsteder en hel lille by for sig med egne gader, pladser, huse, skilte, kirker, katedraler. Og endeligt så han, svævende over Seinestadens indbyggere - han gøs ved synet - ballonerne med deres lynafledere, som berøvede lynet enhver mulighed for at ramme de ubeskyttede huse og forskånede det ganske Paris for himmelens ødelæggende vrede I dette øjeblik nærede Michel ikke noget højere ønske end at skære de tove over, som holdt ballonerne fortøjede, og se hovedstaden gå under i en regn af ild. -Åh, Paris! råbte han og løftede sin knyttede hånd i vrede og fortvivlelse. (Verne, pp. 163-164)

Jules Vernes roman er en science fiction roman, der foregår i' 1960, hvor panoramaet allerede havde været glemt $\mathrm{i}$ over en menneskealder, og hvor Paris havde udviklet sig i en noget anden retning end forudsagt af romanen. Verne har tydeligvis arbejdet med at skrive en balzacsk pariserroman som science fiction og på den måde forny genren, men det lykkes aldrig helten at blive en tidssvarende digter, og han dør efter at have udtalt sin forbandelse over Paris. Læst fra romanens 1960 bliver den panoramiske afslutning et billede på Michels drøm om at vende tilbage til det 19. århundredes Paris, hvilket iøvrigt også afspejles i hans syn på digtningen, som placerer ham som en gammeldags digter, selv $i$ en 1800-tals kontekst. Det modsvares af, at samme slutning læst fra sit skrivetidspunkt, 1860, illustrerer det 19. århundredes panoramiske drøm eller mareridt om det 20. århundredes Paris - et mareridt, som Michel ønsker at destruere ved symbolsk at befri himmelen for de fortøjede balloner. Paris er i romanens 1960 blevet til en uhyre velordnet og kontrolleret by, hvor der ikke er plads til lidenskab og kunstneriske udskejelser. Men det mest interessante og det egentlig fantastiske ved romanen kommer frem ved at læse den fra 1994, hvor den endelig blev udgivet efter at have samlet støv på et loft i over 130 år. Set med nutidens retrospektive blik bliver denne panoramiske slutning med forestillingen om Paris i 1960 iscenesat i 1860 til et interessant og komplekst billede på, hvordan medie- og æstetikhistorien er både uforudsigelig og dog alligevel udvikler sig af visse stier.

For at vende tilbage til denne artikels motto - „Det nye medium resumerer sin tids formproblemer" - så har Verne set det 20. århundrede gennem det 19. århundredes medie. Men i horisonten af det 19. århundredes panorama anes det 20. århundredes medier. Hvad Verne ikke forudså var, at synsmaskinerne skulle ændre struktur i det 20. århundrede. De moderne synsmaskiner er overalt og kræver intet stort udstillingsrum som panoramaets rotunde. Det er allerede ved at være trivielt at nævne Internettets World Wide Web i denne forbindelse. Alligevel kan jeg ikke lade være med at slutte med at pege på det berlinske projekt city.scope, som under mottos som "Den elektroniske horisont” og „panoramabilledet $i$ tid og rum" bruger panoramiske billeder til at dokumentere byudviklingen i det centrum af Berlin, som i mange år har været fraværende i et ingenmandsland; Potsdamer Platz. Her kan man hver dag hente dagsaktuelle panoramabilleder ned fra nettet, se gamle billeder samt en arkitektmodel af pladsen anno 2000. City.scopes egne argumenter for at benytte panoramabilleder drejer sig om panoramabilledets „realitetsnære fremstilling af rum" og dets enkle formidling af at være til stede. Hvis man har'Macintosh' QuickTime VR software, kan man selv styre kameraet og panorere $360^{\circ}$ rundt samt zoome og tilte. Denne software kan hentes på nettet og på samme hjemmeside kan man finde links til eksempler på, hvad denne nye panoramateknologi 
bliver brugt til. Bl.a. kan man finde „The Armchair Travel Company", som sammen med flere andre lignende firmaer har specialiseret sig i virtuelle rejser på nettet med bl.a. panoramabilleder af Picadilly Circus, hvor man kan panorere fra tre forskellige kamerapositioner.

City.scope er et helt konkret udtryk for, hvordan den moderne urbanitet nu kan synliggøres via computere overalt på Internet. Samtidig er den knap så synlig på stedet i det ingenmandsland, som Potsdamer Platz stadig er. Hvis man står af på U-bahn stationen Potsdamer Platz, havner man i en samling murbrokker for enden af trappen op fra undergrunden. Kun via computere og Internet kan man visualisere, hvordan den fremtidige urbanitet ser ud. Men som konkret udtryk for en moderne urbanitet har city.scope selvfølgelig sine begrænsninger. Set fra mit synspunkt er udsigten nok mest tidssvarende, før der kommer for mange fysiske bygninger i vejen for det simulatoriske medieblik, før den nye Potsdamer Platz vokser frem af sit ingenmandsland. Men omvendt forsvinder den fysiske by formodentlig ikke lige med det samme, selvom dens måder at komme til udtryk og repræsentere sig på er under forandring. Forandringer, som i sidste ende vil ændre vores opfattelse af, hvad by og urbanitet er, og hvordan synsmaskinerne og byerne gensidig påvirker og skaber hinanden.

\section{Litteratur}

Balzac, Honoré de: La Comédie humaine, bd. I, III, V, Bourges, Pléiade, Gallimard, 1976-

Bell, David F.: Circumstances - Chance in the Literary Text (University of Nebraska Press, 1993)

Benjamin, Walter: Das Passagen-Werk, Frankfurt/M 1982

Benjamin, Walter: Charles Baudelaire, Suhrkamp, Frankfurt/M 1974

Benjamin, Walter: „Kunstværket i dets tekniske reproducerbarheds tidsalder" in K\&K 77, 1994

Bertelsen, Lars Kiel: „Käleidoskopofoli” in Arbejdspapir 30-96 Center for Kulturforskning, Aarhus 1996

Bolz, Norbert: Am Ende der Gutenberg-Galaxis - Die Neuen Kommunikationsverhältnisse, München 1993

Buck-Morrs, Susan: The dialectics of seeing, MIT-Press 1993

Buddemeier, Heinz: Panorama, Diorama, Photographie - Entstehung und Wirkung neuer Medien im 19. Jahrhundert, Wilhelm Fink Verlag, 1970

Certeau, Michel de: L'invention du quotidien - 1. arts de faire (Gallimard 1990)

City.sope: har udgivet pjecen Der elektronische Horizont og kan findes på Internets World Wide Web på adressen: http:/ / cityscope.icf.de/

Crary, Jonathan: Techniques of the Observer - On Vision and Modernity in the Nineteenth Century, MIT-Press Cambridge Mass, London England 1990

Friedberg, Anne: Window Shopping - Cinema and the postmodern, University of California Press, 1993

Gotfredsen, Lise: Billedets Formsprog, Kbh. 1993

Hansen, Gilbert: „Det panoramiske blik” in Arkitekturtidsskrift B nr. 51 Århus 1994

Larsen, Svend Erik: „„Benjamin, byen, Balzac” in Kritik 114, 1995

Macintosh QuickTimeVR kan findes på Internets WWW på: http:/ / qtvr.quicktime.apple.com/Home.htm

Mitterand, Henri: „Formes et Fonctions de l'espace dans le récit: Ferragus de Balzac" in Le roman de Balzac, Roland le Huenen et Paul Perron, (éd.), (Didier, Montréal, Québec, 1980)

Oettermann, Stephan: Das Panorama, Frankfurt/M, Syndikat, 1980

Plessen, Marie Louise von \& Giersch, Ulrich: Sehsucht: das Panorama als Massenunterhaltung des 19. Jahrhunderts, Basel, Frankfurt/M, 1993

Prendergast, Christopher: Paris and the Nineteenth Century (Blackwell Publishers, Oxford (UK) \& Cambridge (USA) 1992)

Schivelbusch, Wolfgang: Geschichte der Eisenbahnreise, Frankfurt/M 1989 Don Slater: „Photography and Modern Vision” in Chris Jenks (ed.) Visual Culture (Routledge)

Verne, Jules: Paris i det 20. århundrede, Centrum 1995 
Virilio, Paul: Synsmaskinen, Viborg 1989

Zerlang, Martin: „The City Spectacular of the Nineteenth Century” in Arbejdspapir 9, Center for Urbanitet og æstetik.

\section{Noter}

1. Alle oversættelser fra fremmedsproglige referencer er forfatterens med mindre andet er angivet.

2. Henri Mitterand skriver i sin anbefalelsesværdige artikel om rummets former og funktioner i Ferragus at „Balzac semble avoir été le premier à écouter avec tant d'attention les signes qui proviennent de la cité moderne. En 1830, l'émergence de la grande ville révélait plus crûment qu'auparavant le fonctionnement réel de la collectivité." (p. 16). - Christoffer Prendergast beskriver litteraturhistorisk, hvordan den litterære by 'Paris' bliver skabt og udvikler sig: „[But] the most active literary image of this kind for Paris is 'Paris', that is, the Paris of previous narrative incarnations. Several of the novels I shall be looking at re-write, or un-write, the already-written Paris of the novel, principally the Paris of Balzac." (p. 28) - Ferragus. udkom første gang som feuilleton i 1833 og indgår som første del af trilogien Histoire des Treizes, Le père Goriot udkom som feuilleton fra 1834-35.

3. Cf. Crarys første kapitel: „Modernity and the Problem of the Observer".

4. Cf. Larsen, pp. 98-99

5. Selvfølgelig kunne man forestille sig en mere prosaisk oversættelse af dette citat end min rigide oversættelse af det franske: „Insensiblement les articulations craquent, le mouvement se communique, la rue parle." Den eneste (yderst mangelfulde) danske oversættelse af romanen foreslår: „Lyde stiger op fra Gaden, Bevægelse breder sig fra den ene til den anden; Gaden taler." (De Tretten, oversat af G. Casse, Kbh. 1930)

6. Denne kortfattede analyse af Ferragus bliver yderligere udfoldet $i$ et manuskript under udarbejdelse med titlen „,Retorikkens rum eller byens hundredetusinde romaner". Desuden er den understøttet af læsninger af romanen af bl.a. Svend Erik Larsen, David F. Bell og Henri Mitterand. 7. Som det bliver udtrykt i denne chiasme: "Quand on connaît Paris, on ne croit à rien de ce qui s'y dit, et l'on ne dit rien de ce qui s'y fait." (Balzac III, p. 175) („Når man kender Paris, tror man på intet af det som siges, og man siger intet om det, der sker."

8. "kort sagt forklarer hele hendes person pensionen, som pensionen indbefatter hendes person"

9. Dette argument underbygges endvidere på det politiske niveau af Sandy Petrey, der i Realism and Revolution (New York, 1988) i opposition til en traditionel forståelse af realisme som àfspejlende en stabil virkelighedsopfattelse argumenterer for, at realismen netop skal ses i lyset a den nye sproglige og politiske ustabilitet, der opstod i kølvandet af Revolutionen.

10. I Parisisk Panorama har jeg udfoldet disse pointer yderligere i en analyse af Le père Goriot.

11. Teknikken udfoldes første gang fuldt ud i Le père Goriot, men Ferragus benytter teknikken i mindre målestok; da romanen sammen med to andre indgår i samlingen Histoire des Treizes, hvor det samme persongalleri går igen igennem alle de tre korte romaner.

12. Walter Benjamin taler endvidere om det „panoramatiske princip hos Balzac" (Benjamin, 1982, p. 663), hvormed han formodentlig snarere hentyder til Balzacs montering af virkelige, historiske personer i sit fiktive univers. Et andet sted taler Benjamin om en panoramatisk litteratur, som en litteratur der arbejder med typer og fysiognomier, dog uden her at nævne Balzac direkte. (Benjamin, 1992, p. 33)

13. Ferragus har som bemærket af bl.a. Bell tre slutninger, hvoraf Père Lachaise panoramaet er den anden. Den sidste slutning udspiller sig i det på den tid forstadsagtige rum omkring Montparnasse kirkegården. Et moderne urbant rum, der parallelt med Père Lachaise panoramaet beskrives som en blanding af sted og ikke-sted, både inden for og uden for Paris: „espace sans genre, espace neutre dans Paris. En effet, là, Paris n'est plus; et là, Paris est encore. Ce lieu tient à la fois de la place, de la rue, du boulevard, de la fortification, du jardin, de l'avenue, de la route, de la province, de la capitale; certes, il y a de tout cela; mais ce n'est rien de tout cela : c'est un désert." (Balzac, V, p. 901)

14. Luftperspektivet er $\mathrm{i}$ forhold til centralperspektivet en alternativ måde at tegne et rum på en todimensional flade, som iøvrigt var flittigt brugt i panoramaet, hvor man hverken kunne bruge centralperspektivet eller slagskygger til at tegne rummet. Hvor centralperspektivet er en geometrisk grammatik, som ordner rummet og sikrer overførelsen mellem det tredimensionale og det todimensionale, bruger luftperspektivet farven til at opbygge et mere stofligt og atmosfærisk rum, der er mindre homogent og gennemskueligt end det centralperspektiviske, selvom de to perspektiver sagtens kan bruges sideløbende og også er blevet det $\mathrm{i}$ renæssancen. Lise Gotfredsen skriver bl.a. flg. om Leonardo da Vincis brug af skyggevirkninger, som „fylder tomrummet udenom med atmosfære. Ved hjælp af denne sfumato (egl. røg) lader han sine figurer smelte sammen med landskabet på en ny måde og overvinder enhver rest af hårdhed i aftoningen.” (...) „Luftmassen, der ligger mellem øjet og de fjernere genstande $i$ et landskab, og som udvisker konturerne og gør bjergene blålige, finder nu sin maleriske form, og luftperspektivet udvikles. Man kan let forstå, hvad det kommer til at betyde både for landskabsmaleriet og for portrættet. Nu lever ansigterne på en ny måde i at- 
mosfæren, bevæges af stemninger og smil og huden bliver en levende hinde, der modtager lyset og kaster reflekser tilbage." (pp. 127-128) Kort sagt peger luftperspektivet og sfumato effekten både på stemningsbilledet, det indesluttede rum og dette rums heterogenitet udtrykt i de flydende overgange mellem elementerne, modsat centralperspektivets indbydende, gennemsigtige og ordnede rum.

15. Lars Kiel Bertelsen udvikler dette melankolske aspekt yderligere gennem Jonathan Crarys analyser af sansernes adskillelse i begyndelsen af 1800-tallet frem mod et begreb om det, han kalder „det kaleidoskopofile blik". På trods af, at kaleidoskopet og panoramaet er vidt forskellige er de „i deres grundform skabt over samme læst” (p. 14) og har til fælles at de skaber en udelukkende visuel oplevelse. „Kaleidoskopets dynamiske og uhåndgribelige billede, dets ustabile og skønne balance, sætter det i forbindelse med panoramaerne, som fremviste illusionistisk malede og belyste scenerier af fjerne byer og lande." (Ibid.). Senere skriver Bertelsen: „Dermed er der bygget et lag af uformåen og længsel ind i den visuelle perception; blikket imprægneres af savnet og vellysten ved en stadig udskudt og uopfyldt sansemæssig fuldendelse." (p. 17)

16. I 1830 var gaslys stadig en nyhed og man var ved at skifte de gamle dunkelt lysende olielamper ud (jvf. Prendergast, p. 32). Noget af det første gaslys blev iøvrigt installeret i Passage des Panoramas i 1817, hvilket medførte en vis frygt for mulige farer for eksplosion og forgiftning blandt folk (Benjamin, 1982, p. 700). Benjamin citerer iøvrigt en historiker for at mene, at gasoplysning af gaderne var en af Restaurationens hovedværker. I 1814 var Paris oplyst af 5000 gadelys, i 1822 besluttede man at gå over til gas og i 1825 indledtes det første forsøg med at oplyse en plads; Vendôme pladsen. I 1828 var der 10000 gasbrændere i Paris. (Op. cit. pp. 701-702) Vi står således ved tærsklen til byen som spectacle eller det som Buck-Morss kalder The City of Light; byen som fantasmagori - „a magic lantern show of optical illusions, rapidly changing size and blending into one another." (Buck-Morss, 1989, p. 81)

17. Rastignac lever dog videre og optræder hyppigt $i$ andre Balzac románer, såvel som i senere Parisromaner som Flauberts $L^{\prime} E$ Education sentimentale (jvf. Prendergast, p. 29).

18. Denne dannelse gennem nye medier og medieteknologi, som Balzac med Rastignac og Le père Goriot leverer prototypen på, er siden hen ikke blevet mindre væsentlig, jvf. f.eks. de nyeste eksempler som MTV-generationen, technokultur og cyberpunk. George Slusser skriver f.eks. i indledningen til en antologi om cyberpunk: „Looking backward, we see notable examples of fictional worlds tending toward this state of information. Balzac is perhaps the true ancestor of the fictional infosphere." (George Slusser og Tom Shippey (ed.): Fiction 2000, U. of Georgia Press, 1992)
19. „....les éléments considérés sont les uns à côté des autres, chacun situé en un endroit 'propre' et distinct qu'il définit. Un lieux est donc une configuration instantanée de positions. Il implique une indication de stabilité." (Certeau, 1990, p. 173)

20. „...un croisement de mobiles. Il est en quelque sorte animé par l'ensemble des mouvements qui s'y déploient." (Ibid.)

21. „L'espace serait au lieu ce que devient le mot quand il est parlé, c' està-dire quand il est saisi dans l'ambiguiité d'une effectuation, mué en un terme relevant de multiples conventions, posé comme l'acte d'un présent (ou d'un temps), et modifié par les transformations dues à des voisinages successifs. A la différence du lieu, il n'a donc ni l'univocité ni la stabilité d'un 'propre'. En somme, l'espace est un lieu pratiqué." (Certeau, 1990, p. 173)

22. I det hele taget kunne man bl.a. ud fra Balzac overveje forholdet mellem melodramatisk plot og den moderne storbys tid/rum strukturer. Melodramaet, som Balzac benytter det, kan da ses som en genre, der ikke kun skabes af det kapitalistiske læsepublikums krav om at få 'varen' leveret, men også som noget der iscenesættes af byen, og hvordan byens tid- og rumstrukturer i bogstavelig forstand skaber stærke plot. Et andet eksempel på dette kunne være detektivromanen.

23. For en artikel der beskæftiger sig primært med, hvordan panoramiske principper også påvirker byens fysiske arkitektur, se Gilbert Hansen hvis artikel befinder sig $i$ et helt temanummer af arkitekturtidsskriftet $B$ om „Den panoramiske by”. Jeg vil her primært beskæftige mig med panoramaet som medie og synsmaskine.

24. Patentbeskrivelsen er optrykt i Buddemeier. Opfindelsen af panoramaet tillægges hyppigst Barker, men er dog omdiskuteret ligesom der selvfølgelig findes adskillige forløbere. For en udførlig og velskrevet redegørelse for panoramaets historie er Oettermanns Das Panorama uomgængelig. Herhjemme har specielt Martin Zerlang arbejdet med panoramaet, bl.a. i forhold til H. C. Andersen og København. Hans arbejde er p.t. tilgængelig som arbejdspapirer men er under udgivelse.

25. Balzac, III, p. 91 - Rama-snakken udfolder sig derefter over et par sider og vender tilbage på en række markante steder i romanen. - Man kan stadig spore panoramaets invasion i sproget, da panorama idag stort set betyder alt, hvad der er stort, prangende og har det mindste med et skue at gøre. Således er det stort set umuligt at søge i databaser efter oplysninger om panoramaet, da ordet optræder overalt, f.eks. har man som århusianer den tvivlsomme fornøjelse at tage i „Plantorama”. En søgning på Internets World Wide Web giver p.t. 16141 henvisninger, på Statśbibliotekets OnLine fandt jeg 125. De færreste har noget at gøre med det historiske panorama-medie, som det beskrives her. - En sproglig forurening eller innovation om man vil, der kan sammenlignes med hvordan kombinationer med ord som cyber eller virtual breder sig idag. 
26. Tilskuerplatformen og vejen frem til den blev efterhånden også inddraget i illusionen. I 1831 åbnede oberst Jean Charles Langlois en ny og rekordstor panoramarotunde i Rue des Mariais-du-Temple. Panoramaet skulle forestille søslaget ved Navarin og til brug for tilskuerplatformen opkøbte han dækket fra det fra aviserne kendte slagskib Scipion. Desuden afløste han panoramaets underjordiske gang af flere konstruerede kahytter, som publikum gik igennem, mens deres øjnede vænnede sig til det dunkle lys. (Cf. Oettermann, pp. 124-126)

27. De første biografer hed ofte Kosmorama, hvilket understreger slægtskabet. Se også Friedberg, som gennem en medie-, teknologi- og æstetikhistorie sporer rødderne til det filmiske blik i panoramaet, passagerne og stormagasinerne. Et blik hun opsummerer som virtuelt og mobilt.

28. Hvad den tidslige dimension angår blev den forsøgt implementeret i dioramaet (se nedenfor), men panoramaet kan dog også bruges til at afspejle en tidsdimension, hvilket bliver tydeliggiort i Stevens og Gervex "Panorama de l'histoire du siècle" fra Verdensudstillingen i Paris i 1889. Her blev århundredets store mænd fremstillet ordnet $\mathrm{i}$ tidsafsnit $\mathrm{i}$ rotunden. Oettermann skriver: „Begrebet 'panorama' vinder således en ny dimension; i stedet for natur træder historie, og tiden optræder i rummets gevandter." (p. 137) - Fotografer har selvfølgelig også lavet forskellige forsøg med at repræsentere tidens gang gennem panoramiske billeder, bl.a. billeder hvor den samme mand optræder to gange i samme billede og således har bevæget sig, mens billedet blev taget, og tiden er gået. 29. Dioramaet blev opfundet i 1822 som et supplement og tildels en afløser af panoramaet. Opfinderen var teatermaleren og udvikleren af daguerreotypiet, Louis Jacques Mandé Daguerre. Dioramaet „frembragte en optisk illusion i endnu højere grad end i panoramaerne" (Balzac, III, p. 91) og brugte lys og senere lydeffekter til at illustrere tid og bevægelse. Konkret fungerede dioramaet vha. en transparent plade. Når den blev belyst forfra viste den f.eks. et morgenbillede af et landskab, men når frontlyset gradvist blev afløst af bagfrakommende lys skiftede morgenbilledet til et aftenbillede, da det samme landskab var malet i mørkere farver på bagsiden af transparentbilledet. Samtidig kunne bevægelse illuderes via en sindrig brug af komplementærfarver. Lyset var stadig naturligt og blev styret manuelt via klapper i taget.

30. Derfor er og.bliver den teknologi- og mediekritik, der i mediet ser roden til alt ondt, en tragisk kritik, der hæger om en syndefaldsmyte og utopien om et oprindeligt nærvær, hvilket dog ikke forhindrer, at den kan være brugbar som diskussionsoplæg og komme med klare iagttagelser. Men som de Certeau skriver om stærke teoretikere, som ikke har øje for de mangfoldige praksiser, der forskyder og forvandler mediernes magt og kontrolstrukturer: „De forvandler deres dårlige teorier til teorier om dårligdommen." [„Ils muent le malheur de leurs théories en théories du malheur."] (p. 145)
31. Sehsucht opregner 29 bevarede panoramaer i hele verden, heraf halvdelen i Europa. Der er ingen bevarede i Norden eller Paris, men to i London og et i Haag; det efter sigende meget flotte Mesdag panorama. 32. Oversættelse fra Paul Virilio: Synsmaskinen, Viborg 1989, p. 84 33. En form for videreudvikling af panoramaet og dioramaet. Hegel citatet findes i Oettermann, p. 124

34. Se f.eks. Friedberg pp. 59-61

35. Dolf Sternberger: Panorama, Ansichten vom 19. Jahrhundert, Hamburg 1955 , p. 25 citeret fra Schivelbusch, p. 60. Wolfgang Schivelbusch' bog indeholder desuden kapitlet „Das panoramatische Reisen”, som beskriver jernbanerejsen i panoramatiske begreber. Schivelbusch beskriver indgå ende, hvordan perceptionen både under jernbanerejsen (pga. den uvante fart) og i panoramaet mister forgrunden og fornemmelsen af det "Gesamtraum", som forbinder det nære med det fjerne. Norbert Bolz bruger Benjamins berømte aurabegreb til at definere panoramaet og dets andre samtidige fantasmagorier som "teknisk reproducerbare fremmanelser [Beschwörungen] af en fjernhed, hvor nær den end måtte være" (Bolz, p. 106), og han citerer direkte Benjamin for at kalde panoramaerne "fjernhedens og fortidens akvarier", hvilket får Bolz til at tale om en „industrialisering af fjernheden” (ibid.), som udover panoramae bl.a. finder sit udtryk i kolonialisme og turisme. (Jvf. også undertitlen pa Schivelbusch' Geschichte der Eisenbahnreise: Zur Industrialisierung von Raum und Zeit im 19. Jahrhundert)

36. Som i tilfældet med det barokke hofteater, hvor fyrsten var den eneste, der så scenen fra den rette synsvinkel, mens resten af publikum så quasi gennem ham. (Oettermann p. 20)

37. Se Gotfredsen, pp. $98 \mathrm{ff}$.

38. I denne sammenhæng er det oplagt at sammenligne panoramaet med det ligedannede panoptikon, som Foucault har læst som en figur på det borgerlige samfunds kontrolmekanismer (disciplinen og fængselsvæsenet) i Surveillir et punir (Gallimard 1975). De fleste af de teoretikere, som jeg har nævnt i min litteraturliste, foretager og kommenterer da også denne sammenligning. Da det er en omfattende diskussion, der kræver sin egen artikel, vil jeg nøjes med at påpege vigtigheden af ikke umiddelbart at sætte lighedstegn mellem de to bygningsteknologier, som det mere eller mindre indirekte gøres af Virilio og Prendergast. Der er selvfølgelig forskel på en kontrolteknologi, og den måde den bruges i medier og æstetik. Den æstetiske brug er netop med til at forskyde og gradvist demontere kontrolteknologiens restriktioner i forhold til den daglige praksis. At sætte lighedstegn mellem panorama og panoptikon ville svare til at sætte lighedstegn mellem overvågningskameraer og videokunst. I en optimistisk læsning er den æstetiske brug netop vigtig som en bevidstgørelse, der muliggør en dagligdags omgang med kontrolteknologierne. Omvendt er der selvfølgelig ingen tvivl om, at de to 
teknologier er beslægtede. Oettermann stiller panoramaet og panoptikonet op i en dialektiske modstilling, der præcist udtrykker, hvordan de to teknologier bruger samme strukturelle træk til potentielt forskellige formål: „Panorama og panoptikon er som skoler for blikket både identiske og modsætninger på samme tid. I panoramaet lærer man det blik at kende, gennem hvilket man i panoptikonet bliver opdraget. " [„Im Panorama wird der Blick gelernt, durch den im Panopticon gelehrt wird."] (p. 36).

39. Med denne kommentar peger Oettermann desuden på, hvordan panoramaet gennem adskillelsen af sanserne oplærte det fetichistiske vareblik på verden, der som figur har butiksrudens adskillelse af syn og berøring. (Se Friedberg og Buck-Morss' kapitel „Mythic History: Fetish")

40. Pga. hastigheden lærer togpassagererne efterhånden at stirre ud i den forholdsvis langsomt bevægende horisont i stedet for det flimrende nære. (Cf. Schivelbusch, pp. 54 ff.)

41. Nadar var pseudonym for Gaspard-Felix Tournachon (1820-1910), som var en kendt karrikaturmaler og fotograf i Paris. I 1856 eller 1858 lavede han verdens første luftfoto fra ballon og i 1858 begyndte han at fotografere ved elektrisk lys og lavede bl.a. en serie billeder fra Paris' kloakker.

42. Andre synsteoretikere som Anne Friedberg går endda så vidt som til at finde en forhistorie til det post-moderne i 1800-tallets synsmaskiner.

Don Slater er også interessant $\mathrm{i}$ hans demonstration af, hvordan fotografiske teknikker samtidig skaber et moderne publikum og et publikum for moderniteten. Denne diskussion om modernitet og post-modernitet er selvfølgelig langt hen ad vejen en terminologisk diskussion, men peger samtidig på en mulig restrukturering af æstetikhistorien og en genovervejelse af de realistiske og populærkulturelle strategier fra 1800-tallets første halvdel og midte.

43. „Omkring 1900 havde den tekniske reproduktion nået en standard, ud fra hvilken den begyndte ikke blot at gøre totaliteten af overleverede kunstværker til sit objekt og at underkaste deres virkning de dybeste ændringer, men også erobrede sig en selvstændig plads blandt de kunstneriske teknikker." (Benjamin, 1994, p. 17)

44. Hvornår dette skift indtræffer er selvfølgelig svært at sætte nøjagtig dato på. Som det kan ses i noten ovenover siger Benjamin omkring år 1900. Virilio peger på 1. Verdenskrig (jvf. Virilio, p. 35) men er dog også inde på opdagelsen af fingeraftrykket som et latent billede, der tages i brug i kriminalforskning i Storbritannien i 1897. En tredje teknik der har været væsentlig i denne overgang fra syn til synliggørelse er selvfølgelig röntgenfotografiet, som blev opfundet i 1895. - Meget tyder kort sagt på et markant skift omkring år 1900, hvor panoramaet forsvinder. 